\title{
UNA NUEVA ESPECIE DE Shevtchenkella (ACARI, PROSTIGMATA, ERIOPHYIDAE) DE ARGENTINA
}

\author{
María C. Ballari ${ }^{1}$, Sara L. Quintana de Quinteros ${ }^{2}$, Carlos H.W. Flechtmann ${ }^{3}$ \\ ${ }^{1}$ Finca Experimental “La Posta”. Latser SA. Jujuy, Argentina. E-mail: celesteballari@ gmail.com \\ ${ }^{2}$ Facultad de Ciencias Agrarias. Universidad Nacional de Jujuy. Jujuy, Argentina. E-mail: zoolagricola@ fca.unju.edu.ar \\ ${ }^{3}$ Departamento de Entomologia e Acarologia, Escola Superior de Agricultura "Luiz de Queiroz", Universidade de São Paulo, \\ Piracicaba, São Paulo, Brasil, CNPq-Brazil Researcher. E-mail: chwflech@usp.br
}

\section{ABSTRACT}

Shevtchenkella marceloi Flechtmann, n.sp. is described and figured from female, larva and nymph specimens, from Tessaria dodonaeifolia (Hook. y Arn.) Cabrera from Jujuy, Argentina. Remarks on Shevtchenkella species from South America are presented.

Keywords: Taxonomy, Eriophyoidea, Shevtchenkella n.sp.

\section{A NEW SPECIES OF Shevtchenkella (ACARI, PROSTIGMATA, ERIOPHYIDAE) FROM \\ ARGENTINA} RESUMEN

Se describen e ilustran especímenes de Shevtchenkella marceloi Flechtmann, en la forma de hembra adulta, larva y ninfa, encontrados sobre Tessaria dodonaeifolia en Jujuy, Argentina. Se presentan observaciones sobre las especies Shevtchenkella de América del Sur.

Palabras-clave: Taxonomía, Eriophyoidea, Shevtchenkella n.sp.

\section{UMA NOVA ESPÉCIE DE Shevtchenkella (ACARI, PROSTIGMATA, ERIOPHYIDAE) DA ARGENTINA}

\section{RESUMO}

Shevtchenkella marceloi Flechtmann, n.sp. é descrita e ilustrada a partir de fêmeas, larva e ninfa encontradas em Tessaria dodonaeifolia (Hook. \& Arn.) Cabrera em Jujuy, Argentina. São apresentadas observações sobre as espécies de Shevtchenkella da América do Sul.

Palavras-chave: Taxonomia, Eriophyoidea, Shevtchenkella n.sp.

\section{INTRODUCTION}

A study of the relation between an undetermined Paraphytoptus species (Eriophyidae) and tobacco, Nicotiana tabacum L. was initiated in the Province of Jujuy, Northern Argentina. In that study, weeds present in tobacco fields were examined as potential alternative hosts for that mite.

Examination of leaves of "chilca dulce" Tessaria dodonaeifolia (Hook. y
Arn.) Cabrera (Asteraceae, Compositae) disclosed an eriophyid mite which proved to be a species new to Science and is herein described from females, larva and nymph. All measurements are given in micrometers $(\mu \mathrm{m})$ and refer to the length of the structure, unless otherwise stated. For each species, the holotype female measurement precedes the corresponding range for paratypes (given in parentheses). 
Shevtchenkella marceloi Flechtmann, n.sp.

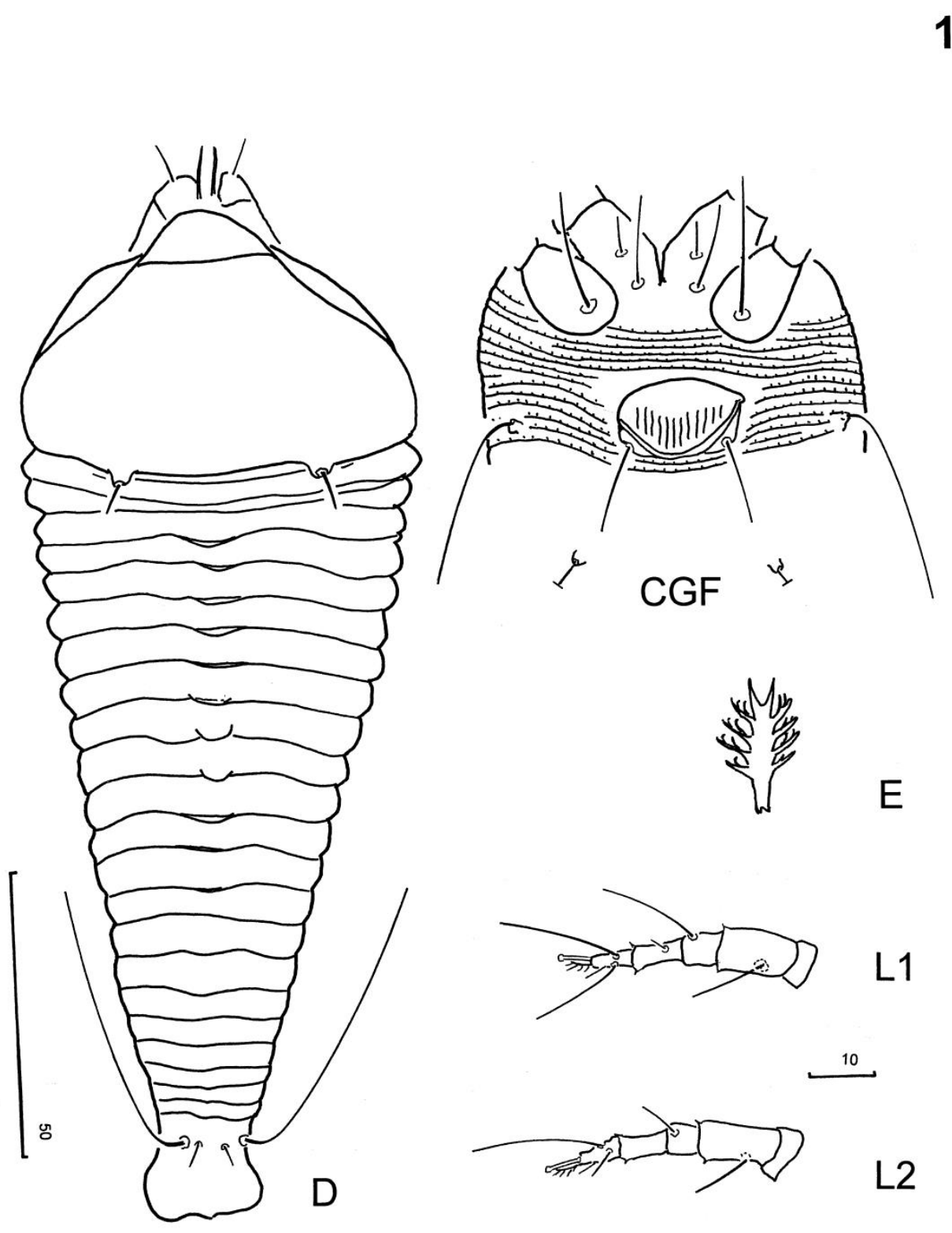

Figura 1. Shevtchenkella marceloi Flechtmann, n.sp. Female. CGF coxigenital region; D dorsal habitus; E empodium, enlarged; L1 leg I; L2 leg II. 

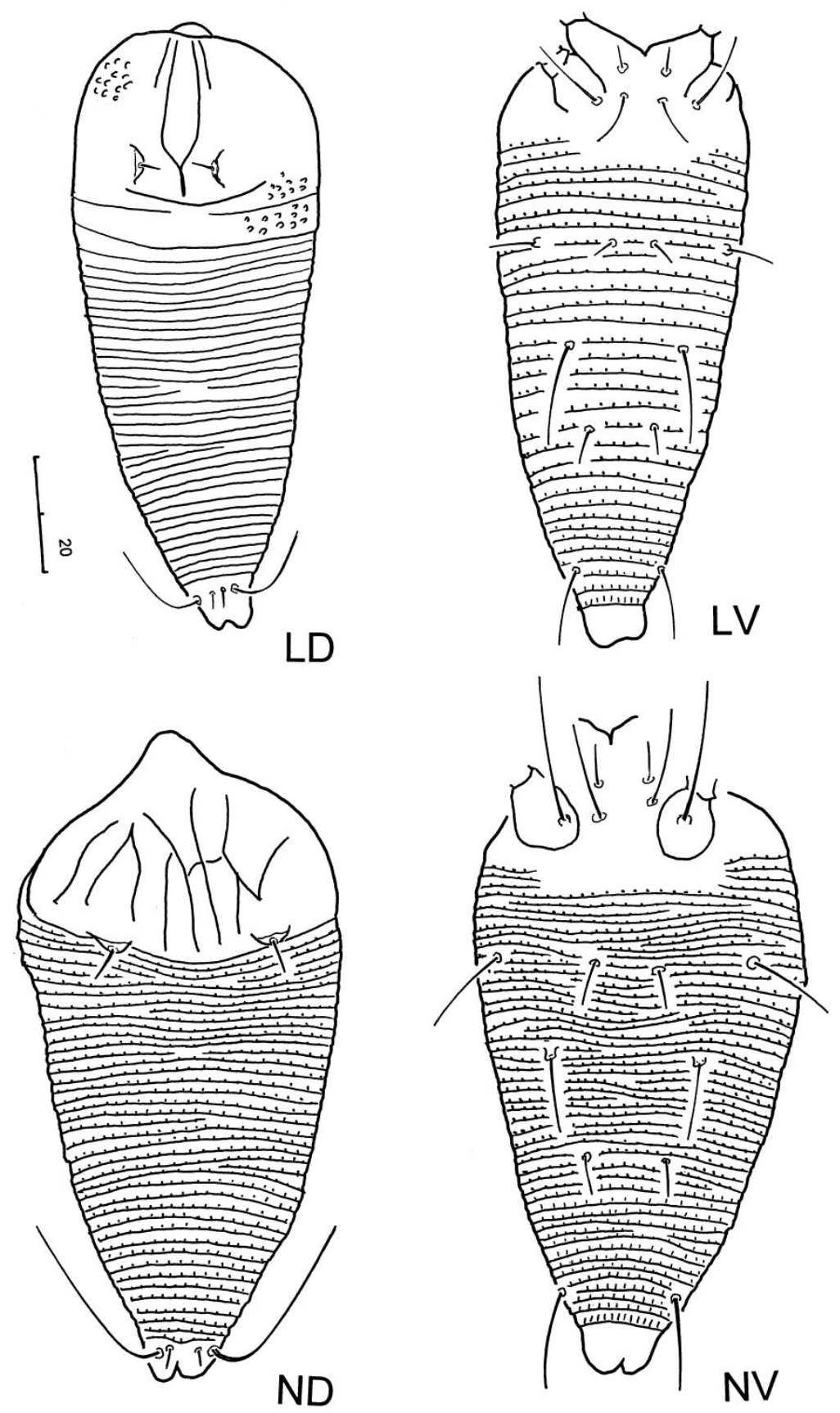

Figura 2. Shevtchenkella marceloi Flechtmann, n.sp. Immatures. LD larva, dorsal habitus; LV larva, ventral habitus; ND nymph, dorsal and NV nymph ventral habitus. 
DIAGNOSIS - Anterior lobe of prodorsal shield broadly rounded; empodia five-rayed; epigynum with 14 longitudinal lines; proximal seta on coxisternum III $(3 a)$ length about two thirds the distance to first ventral seta $(d)$.

FEMALE - (specimens measured 6) Body elongate, fusiform, 183 (161-202), 71 (6174) wide. Gnathosoma obliquely downcurved, dorsal pedipalp genual seta (antapical seta) 6 (5-7), pedipalp coxal seta (basal seta) 3 (2-3); chelicerae 19 (17-22). Prodorsal shield 50 (46-52) including a 9 (9-11) frontal lobe; shield 73 (71-75) wide. Frontal lobe base 24 (23-26) wide. Scapular tubercles on shield rear margin, 35 (31-37) apart; scapular seta (sc) short, 7 (6-8), likely directed upward in live specimens and directed backwards in mounted ones. Legs with all usual setae present. Leg I 35 (3439); femur 11 (8-11), basiventral femoral seta $(b v) 11$ (10-13); genu 6 (5-7), antaxial genual seta (l’) 21 (17-23); tibia 7 (7-9), paraxial tibial seta $(l$ ') $3(3-5)$; tarsus 8 (6-8), paraxial tarsal seta (ft') 19 (18-22), antaxial tarsal seta (ft') 23 (22-24), paraxial unguinal tarsal seta ( $u$ ') 5 (4-5), solenidion 6 (6), knobbed, empodium 5 (5), five-rayed. Leg II 33 (33-36); femur 10 (8-11), bv 11 (10-12); genu 6 (5-6), l" 4 (4-6); tibia 6 (6-8); tarsus 7 (6-7), ft' 4 (4-5), ft'” 20 (20-23), u' 5 (5), solenidion 6 (5-7), knobbed, empodium 5 (45), five-rayed. Coxigenital region: coxae I fused, prosternal apodeme slightly bifurcate distally, 6 (5-8); coxal plates unornamented, smooth; anterolateral seta on coxisternum I (1b) 8 (7-12), 13 (12-15) apart; proximal seta on coxisternum I (1a) 24 (22-30), 10 (8-11) apart; proximal seta on coxisternum II $(2 a)$ 35 (35-45), 27 (26-33) apart. Coxisternal area with 5 (5-6) annuli, faintly microtuberculate. Genitalia: 22 (20-25) wide, 14 (14-16 long); epigynum with 14 (12-15) longitudinal lines. Proximal seta on coxisternum III (relocated to lateral margin of genitalia) (3a) 13 (11-16), extending over two thirds the distance of basis of $3 a$ to opisthosomal first ventral seta $(d)$. Opisthosoma: dorsally flattened, with dorsomedian longitudinal ridge flanked on each side by a shallow trough over half of opisthosomal length. Lateral seta (c2) long, 35 (33-46), extending far behind basis of opisthosomal seta $d$; on ventral annulus 1 (12) counting from genitalia rear margin; first ventral seta $(d) 44$ (31-52), 35 (29-35) apart, on annulus 15 (15-19); secnod ventral seta (e) 11 (10-12), 18 (15-19) apart, on annulus 32 (31-38). Third ventral seta $(f) 25$ (23-28), 22 (18-26) apart, on annulus 47 (47-54) or 5 th $(5$ th) from rear. Total ventral annuli 51 (51-58), microtuberculate, microtubercles beadlike becoming somewhat elongate towards lateral margins and posterior annuli. Total dorsal annuli 23 (23), smooth. Lateral lobes rounded, blunt. Caudal seta (h2) 56 (56-58); accessory seta (hl) 5 (4-5).

MALE - not seen.

NYMPH - (one specimen measured) Spindle shaped, 110 long, 55 wide. Chelicerae 17 long. Prodorsal shield 37 long, 48 wide; scapular setae 6 long, 26 apart, on shield rear margin. Shield with a design of several longitudinal and one transverse line, as figured. Opisthosoma dorsum with 41 annuli.microtuberculate; ventrally six annuli anteriorly to setae $3 a$ and $c 2$, which are in a transverse line, and 38 annuli posteriorly; all annuli microtuberculate.

LARVA - (one specimen measured) Spindle shaped, elongate, 104 long, 42 wide. Prodorsal shield with two submedian longitudinal lines extending over anterior two thirds of shield; at level of scapular tubercles, they merge into one median line, extending posteriorly over one third of shield. One pair of lines extend over anterior one third of shield, parallell to admedian lines. Scapular tubercles ahead of rear shield margin, 26 apart; scapular seta 6 long, probably directed upward in life; in microscopic preparation scapular tubercles folded centrally. Otherwise, shield surface rough. One slightly arched line extends 
transversely at the end of shield median line, and is here considered the prodorsal shield rear margin for measuring purpose, although posteriorly a band of rough cuticle is present. Total dorsal annuli 39. Ventral annuli are wider; six annuli anterior to setae $3 a$ and $c 2$ and 27 annuli posteriorly, all microtuberculate.

TYPE MATERIAL - female holotype, 10 female, one nymph and one larva paratypes, from leaves of Tessaria dodoneifolia (Hook. y Arn.) Cabrera (Asteraceae), Jujuy, Argentina, GPS $24^{\circ} 22^{\prime} 51^{\prime \prime} \mathrm{S}, 65^{\circ} 08^{\prime} 22^{\prime \prime}$ W, June 2013, collected by M. C. Ballari, on 9 microscopic preparations in the Acari Collection of Departamento de Entomologia e Acarologia, Universidade de São Paulo ESALQ, Piracicaba, SP, Brazil.

RELATION TO HOST - vagrants; no visible damage.

ETYMOLOGY - I take pleasure in naming this species for Mr. Marcelo Ballari, father of Maria Celeste, a devoted and passionate observer of nature and who inspired his daughter in the study of Biology.

REMARKS - The new species resembles Shevtchenkella stefneseri Craemer, 1996, but differs in presenting an apparently fixed number of 23 dorsoopisthosomal anuli (1718 in S. stefneseri), long lateral seta (c2), extending past the basis of opisthosomal first ventral seta $(d)$ (c2 short less than half the distance to d in S. stefneseri); long first pair of opisthosomal ventral seta $(d)$, which extends past basis of second pair $(e)(d$ length about half the distance to $e$ in $S$. stefneseri). The two species há different host plants: the new species was collected from an Asteraceae and $S$. stefneseri from a Verbenaceae (Lantana camara L.), both in South America: the new species in northern Argentina, S. stefneseri from plants originating in Paraguay.

The imatures, larva and nymph, of the new species can be readily distinguished by characters other than size. The scapular tubercles are well ahead of prodorsal shield rear margin in the larva, while in the nymph they are on the rear shield margin as in the female. Shield design is also different, as illustrated. Opisthosomal ventral annuli are fewer and wider in the larva, while in the nymph annuli are equal dorsoventrally. This is one more exception to the general agreement (LINDQUIST, 1966) that criteria to separate the two imature stages in Eriophyoidea are lacking (see FLECHTMANN, 2010).

Two species of eriophyids have previously been recorded from plants in the family Asteraceae, from Argentina. Kieffer $\&$ Herbst (1911), in their paper on galls from Chile, included a description of a gall on bark of Baccharis subulata Hook from Mendoza, Argentina and gave Eriophyes baccharidis as its etiological agent. Neither description nor figure of the mite was given. Corti (1917) described and figured an eriophyid mite from leaf galls of Baccharis salicifolia Pers., from Cordoba, Argentina, and unaware of Kieffer \& Herbst's species, also called Eriophyes baccharidis. Since this name was preoccupied, Amrine \& Stasny (1994) proposed the name Aceria cortii for Corti's species.

\section{SOUTH AMERICAN SPECIES OF Shevtchenkella}

The new species is the seventh species of Shevtchenkella described from South America and the first from a Solanaceous plant. The other species are:

Shevtchenkella stefneseri Craemer, 1966, described from Lantana camara L. (Verbenaceae), collected at quarantine in Jamaica on plants originating from Paraguay.

S. gnatholoba Flechtmann, 1999, described from Trema micrantha (L.) Blum., Ulmaceae, collected in Mogi Guaçu, São Paulo, Brazil.

S. schinopsidis Navia \& Flechtmann, 1999, described from Schinopsis brasiliensis 
Engl., Anacardiaceae, collected in Brasília, DF, Brazil.

$\begin{array}{lcr}\text { S. ligulata Santana \& Flechtmann, } \\ \text { 2002, described } & \text { from } & \text { Enterolobium } \\ \text { contortisiliqum } & \text { (Vel..) } & \text { Hauman, }\end{array}$ Leguminosae - Mimosaceae, collected in Curitiba, Paraná, Brazil.

S. macrorrhina Santana \& Flechtmann, 2002, same data as for $S$. ligulata.

S. desmodivagus Flechtmann \& Moraes, 2002, described from Desmodium barbatum (L.) Benth., Leguminosae Papilionaceae, collected in Piracicaba, São Paulo, Brazil.

\section{ACKNOWLEDGEMENTS}

We thank Dr. Osvaldo Ahumada Cátedra de Botánica General, Facultad de Ciencias Agrarias, Universidad Nacional de Jujuy - for the weed's identification.

\section{REFERENCES}

CORTI, A. 1917. Specie nuove di Eriofidi cecidogeni del territorio argentino. Broteria, Ser. Zool., v.15, n.2, p.108112.

CRAEMER, C. 1996. Eriophyoidea (Acari) associated with Lantana camara L., with descriptions of two new species. African Plant Protection v.2, n.1, p.59-66.

FLECHTMANN, C.H.W. 1999. Four new species of Eriophyid mites (Acari: Diptilomiopidae, Eriophyidae) from Trema micrantha (L.) in Brazil with remarks on "hypostomal or infracapitular lobes" and "solenidion phi" on tibia I. International Journal of Acarology n.25, n.3, p.173-181.

FLECHTMANN, C.H.W. 2010. Two new Epitrimerus Nalepa (Eriophyidae, Prostigmata) species from Brazil and further remarks on the immature stages of a few eriophyoid species. Systematic and Applied Acarology v.15, n.1, p.7180.

FLECHTMANN, C.H.W. ; MORAES, G.J. de. 2002. New Brazilian eriophyid mites (Acari:Eriophyidae). Zootaxa n.75, p.112.

KIEFFER; HERBST, P. 1911. Ueber Gallen und Gallentiere aus Chile. Centralblatt fuer Bakteriologie, Parasitenkunde und Infektionskrankheiten v.29, n.2, p.696-704.

LINDQUIST, E.E. 1996. External anatomy and notation of structures. In: Lindquist, E.E., Sabelis, M.W. \& Bruin, J. (Eds.) Eriophyoid mites - their biology, natural enemies and control. Elsevier, Amsterdam, World Crop Pests v.6, p.130.

NAVIA, D.; FLECHTMANN, C.H.W. 1999. Two new eriophyid mites (Acari: Eriophyidae) from Schinopsis brasiliensis Engl. (Anacardiaceae) from Brazil. International Journal of Acarology v.25, n.3, p. 183-188.

SANTANA, D.L.Q.; FLECHTMANN, C.H.W. 2002. Two new species of Shevtchenkella (Acari: Eriophyidae) from a Brazilian forest tree. International Journal of Acarology v.28, n.3, p.261-265.

Recebido em: 21/10/2013 Aceito para publicação em: 25/11/2013 